Anne Jerslev

\title{
Rejsen til det mørke kontinent - Om Blue Velvet
}

\section{I.Inledning}

Jeg skal i det følgende besk ftige mig med den amerikanske filminstriktør David Lynch's film Blue Velvet fra 1987. Efter en kort introduktion til instruktørens produktion og univers (afsnit 2), vil jeg foretage en psykoanalytisk orienteret læsning af filmen, i hvilken jeg vil diskutere dens ambivalente fremstilling af elementer i en mandlig subjektkonstruktion. Jeg vil vise, hvordan filmen på den ene side, i sin struktur, søger bagud, bag om den »mandlig/kvindelige« polaritet, som kønsidentitetsdannelsen endelig konstituerer, i og med gennemspilningen af Ødipuskomplekset (afsnit III-VI). På den anden side vil jeg spørge, om den ikke samtidig opretholder en slags ødipal orden, i og med sin dybest set autoritative udsigelse (afsnit VIII). Endelig vil jeg diskutere Blue Velvet i forhold til den nyere, overvejende amerikanske feministiske filmteoris diskussion om "kønnede tilskuerpositioner (gendered spectatorship) og dens analyser af, hvordan den klassiske narrative film konstituerer "mandlige « tilskuerpositioner. Jeg vil bruge Blue Velvet i forhold til en nuancering af den teoretiske forestilling om, at den mandlige tilskuers blik og begær nødvendigvis må struktureres entydigt og fikseret i en accept af og identifikation med filmens (ødipale) projekt, der (ubevidst) drejer sig om at bemestre det kvindelige. Og filmen kan bruges i forhold til de teoretikere, der betragter den kvindelige og den mandlige tilskuers tilbud om identifikationer fra den (klassiske) narrative film som mindre entydige og mere flydende. ${ }^{1}$

\section{II.David Lynch - en auteur}

Blue Velvet er David Lynch's fjerde langfilm. Efter kultfilmen, den sort-hvide Eraserhead fra 1979, lavede han i 1980 den ligeledes sorthvide Elephant Man (da. Elefantmanden) og i 1984 storproduktionen Dune (da. Klit).

Eraserhead fremstiller en sær og angstfyldt verden. Den er en slags surrealistisk mareridt uden noget egentligt handlingsskelet. Dens rum, der på én gang er klaustrofobisk og omfatter hele universet, er befolket af mærkelige skabninger - forst og fremmest den passive og 
afmægtige Harry med det barnligt-gamle ansigt og hans »baby«, en slags for tidligt født foster, der næsten uden krop og slimet, som var det uden hud, ligger på en pude og græder. Filmen kan ses som en rejse i kroppenes indre og ubevidste dele, tematiserende først og fremmest ukoordinerede, usammenhængende kropsforestillinger: væsker der flyder ud af dyrs og menneskers kroppe, blod der sprøjter, sædcellelignende orme, der drysser ned fra lofter, organer der dunker uden et beskyttende lag af hud til at holde sammen på dem.

Eraserhead er sociologisk interessant i den forstand, at forst da den blev sat på midnatsprogrammet i en biograf i Los Angeles, blev den bemærket og fik en kultlignende status på linje med The Rocky Horror Picture Show. Men set i relation til Lynchs senere film (såvel som hans to foregående korte filmeksperimenter, den 4 min's The Alphabet fra 1968 og den 34 min's The Grandmother fra 1970) kan Eraserhead også ses som en slags pensel-prøve, hvor en stor del af de visuelle (og auditive) udtryk og de temaer, han senere tager op, konstitueres: Fascinationen af rummet, dels dets øde og uendelige lyd og dels svævende klumper af materie, der kan sprænges når som helst, føres videre i Dunes monumentale mainstream-kulisser; det samme gor ormene, der i Eraserhead både er billede på kroppen og muligvis den seksualitet, Henry er bange for, mens de i Dune repræsenterer en ubunden kraft, der i tæmmet form kan stilles i det godes tjeneste. Teaterscenen er et centralt symbol både i Eraserhead, Elephant Man og Blue Velvet; den kan markere overgange eller pege pă flydende grænser: mellem indre og ydre virkelighed og mellem fiktion og ikke-fiktion. Med en slags spejleffekt peger scenesymbolikken på én gang ud mod biograftilskueren og ind mod filmens aktører. Den henviser til udsigelsen og har tematisk funktion - mest gennemfort i Elephant Man, hvor blikket hos biografpublikum og de mange forskellige publikummer i filmen bliver et og det samme: først det forventningsfuldt nyfigne blik på den hættetilslørede, vanskabte John Merrick og dernæst maskens blik, skuespillerens pokeransigt (som filmens fejrede skuespillerinde, Mrs Kendall, er den ypperste i), blikket der ser og ser den hæsligt forvredne krop og hele tiden vil se den skønne sjæl. Denne krop seksualiserer filmens ene publikum; proletariatet, der ikke har lært at sminke og forvandle sin lyst. Men fascinationen af kroppen og seksualiteten er samtidig også det punkt, alle Lynch's film drejer om, og som han prøver at fă hold på; bag billederne af de deforme kroppe og angstbesatte seksualitetsfantasier kan instruktørens oeuvre ses som (meget forskellige) forsøg på at få hold på den svære personlighedsudvikling i et mandigt individ. Hvor Eraserhead - i den ene ende er en disparat samling kropsfantasmer over et handlingsskelet, og hvor Elephant Man og Dune på én 
gang fremhæver kroppen og hyller den ind i en kristen, henholdvis gammel - og nytestamentlig frelsermytologi, dér beskæftiger Blue Velvet $\mathrm{sig}$ - i den anden ende - med det mandlige subjekt, i en krop, der er hyllet i lillebyungersvendens, hovedpersonen Jeffreys, form.

\section{III.En rejse indad}

Blue Velvet handler om denne unge mand, der er forelsket i en lyshåret prinsesse, datter af politimanden, sergent Williams. En dag finder Jeffrey et afhugget øre, som han bringer til Williams. Draget af mysteriet, og fordi Sandy har oplysninger om gåden og om sammenhængen mellem øret og en vis natklubsangerinde, Dorothy, bliver han vidne til og efterhånden del af en historie om mord, kidnapning, narkotika og sadomasochistisk seksualitet, der har rødder både i politiets rækker og i den sadistiske bagmand Frank, der har kidnappet Dorothys barn.

Hjulpet af politiet reder Jeffrey tilsidst mysteriets tråde ud. Efter at Frank nær har tævet Dorothy til døde, møder han i filmens slutscene - i et endeligt opgør - Frank og dræber ham.

Som sådan indeholder filmen narrative forløb et klassisk projekt, der drejer sig om at løse en gåde om en kvinde. Men i og med at Jeffrey nærmer sig Dorothy, nærmer han sig også sig selv. Så filmen vender samtidigt det undersøgende blik den anden vej og siger, at den endelige gåde snarere er manden - i.e. Jeffrey.

Spørgsmålet er så, hvad han finder, på detektivisk rejse i sig selv og mod sig selv.

Blue Velvet handler om opløsning af strukturer og om, at intet er, hvad det ser ud til at være. Den handler insisterende om, at der er noget under overfladen, som altid vil vise sig, og især i det, der prætenderer at være eller ser mest ud som idyl. Den handler om $\gg$ the dark continent «, som Freud kaldte det ubevidste, om de skjulte og fortrængte dele af personligheden - især af den mandlige - men også af kulturen og af familieinstitutionen. Og med sin parodisk idylliske indledning, der afsluttes med en voldsom beskrivelse af, hvordan en fader og hus- og haveejer får sin egen vandslange i nakken - med et slagtilfælde til følge - synes den allerede fra starten at sige, at jo mere idyllen er baseret på at holde det nede, så meget desto voldsommere og destruktivere kommer det frem.

Filmen foregår i en tid, der bærer mindelser om 50'erne (hvis vi kigger på tøjet og lytter til titelsangen Blue Velvet i hvert fald) - et tidsrum der i Europa som i USA kan karakteriseres som fortrængningens årti. Men der er også elementer, der ikke hører til 50'erne - 
Jeffreys ring i øret, f.eks. og kassettebåndet, Frank tager frem, som først blev almindeligt udbredt i slutningen af 60'erne. Filmen foregår da snarere $i$ en slags moderne al-tid, som peger på, at dens univers er et psykisk, mere end et socialt rum.

At vi bevæger os ned under overfladen og ind i et psykisk rum, demonstrerer filmen meget tydeligt - næsten overtydeligt - i 1 . Scenes sidste indstilling. Kameraet penetrerer græsset for at finde ned til det uhyggelige, biller i hundredevis, der på lydsiden summer infernalsk, samtidig med at vi hører en lyd som fra et wc, der skyller ud. Derefter klippes til et billede af en reklamestander: "Welcome to Lumberton " smiler en kvinde $\mathbf{i}$ hvidt på reklamen, mens vi på lydsiden først hører indsmigrende kvindesang, og derefter taler en smart DJ-radiospeaker absurd sadistisk om, at solen skinner ude i skoven i Lumberton, så man skal frem med kædesavene, og når man hører lyden af træet, der falder, er klokken 9.30 .

Jeg vil betragte Blue Velvet som en film, der primært handler om en mand - Jeffrey. Det er hans projekt, vi følger, og på baggrund af det kan man sige, at filmen - bredere - indeholder refleksioner over det mandlige. Jeg vil da se kvindefigurerne som repræsentationer af sider af den mandlige hovedperson - som de mere kvindelige - besværlige og uhăndterlige -- sider i ham eller - med andre ord det som Jung kalder animaen. Kun som sådan bliver de overhovedet interessante $\mathrm{i}$ filmen, men da bliver de også interessante.

Man kan også sige, at psykiske komplekser i det mandlige subjekt bliver forskudt til kvindefigurerne. Der repræsenteres de. Således spaltet $\mathrm{i}$ repræsentationen udtrykkes den mandlige subjektivitet pa den ene side som et konfliktfyldt sted. Og ved at blive forskudt til kvinderne kan man på den anden side sige, at konflikterne søges bemestret gennem den filmiske diskurs.

Samtidigt med dette bemestringsforsøg er projektet i Blue Velvet da at undersøge, om og hvordan kvindelige elementer kan integreres $\mathrm{i}$ det mandlige subjekt, i stedet for at blive fortrængt eller fornægtet: Til trods for at Dorothy lemlæstes af filmens anden mandlige hovedperson, den sadistiske Frank, dør hun ikke. På den måde er Blue Velvet en interessant undtagelse blandt de senfirserfilm, der kan siges at handle om familien og den mandlige subjektivitet $\mathrm{i}$ krise, repræsenteret $\mathrm{i}$ en (mere eller mindre) dæmoniseret kvindefigur, der truer familieidyllen - eller den familieidyl, filmene postulerer, men som de knap selv tror på. Hvor disse films projekt synes at være at fortrænge og eliminere det kvindelige, tager Blue Velvet det frem og kigger på det. ${ }^{3}$ 


\section{Et preadipalt projekt}

"I don't know if you are a detective or a pervert«, siger filmens unge pige Sandy til hovedpersonen Jeffrey i starten af filmen, lige inden han skal op i sangerinden Dorothys lejlighed. Og han svarer frejdigt, undvigende og koket, at »that's for me to know and you to find out «. Når hun stiller spørgsmålet nu, er det fordi, hun og Jeffrey netop har overværet Dorothy Vallens synge. Og det blik Jeffrey sender op mod Dorothy, er ikke detektivens distancerede, køligt gennemborende blik, det er ikke »den professionelle voyeurs $\alpha^{4}$, Lovens ordnende og strukturerende blik. Det er derimod blikket fra en »voyeur«, der mere magtesløst er henvist til partialdriften synssansen og derfor nærmest synes at smelte sammen med sangerinden. ${ }^{5}$

Sandy făr forst svaret på sit spørgsmål i slutningen af filmen, men tilskueren făr det snart efter: Jeffrey er »detective» præcist fordi han er »a pervert« - og omvendt. Hans begær efter viden og hans voyeuristiske drift kan ikke skilles fra hinanden.

Kigger man på Blue Velvets måde at adressere biografpublikum på, tvinger den konstant tilskueren til at reflektere over sig selv som tilskuer, på enkeltscenens niveau, men også i den overordnede struktur: Filmens slutscene starter med en udtoning til et nærbillede af et øre, som kammeraet går ud af, lige som det på et tidligere tidspunkt $\mathrm{i}$ filmen gik lige ind i Jeffreys øre. Derefter kører det helt tæt hen på et lukket øje, der åbner sig, og da kammeraet kører lidt ud, ser vi, at det er Jeffrey, der er vågnet af en slummer. Som tilskuer må man da spørge sig: er det, vi har set Jeffreys »virkelighed «, eller er det hans »drøm《. Og dermed tvinges vi til at tage vores første forståelse eller læsning af filmen op til fornyet overvejelse og gennemgang. Vi må så at sige overveje, om vi skal se på billederne med andre øjne.

Således betragtet kan Blue Velvet karakteriseres som en metafilm, en film om at se på film. Samtidig med at den indeholder at narrativt forløb og benytter sig af visse af suspensefilmens konventioner, gør den også opmærksom på sin karakter af illusion, teater: det blå fløjlsforhæng, der omkranser filmen, kan ses som et scenetæppe, og både $\mathrm{i}$ starten og slutningen åbner filmen sig mod tilskueren, som om den vidste, at den blev set på, ved at lade en - $\mathbf{i}$ øvrigt for fortællingen ligegyldig - brandmand vinke ud mod tilskuerne. Som symbolsk figur er det selvfølgelig ikke ligegyldigt, at denne aktør netop er en brandmand. Brandmænd slukker ild og modvirker dermed forandringer. Og dog er alene brandbilens eksistens her et tegn på, at huse kan brænde. Brandbilen bliver da ligesom en række andre elementer $\mathrm{i}$ denne åbningsscene et tegn på, at det ulmer under hverdagslivets 
blanke overflade. Men brandbilen er også et af flere eksempler på, at filmen bryder med den traditionelle narrative film ved at åbenbare sin karakter af tekst, diskurs, i stedet for at skjule sig bag historien, for at bruge Christian Metz' distinktion. ${ }^{6}$

Jeg har indtil nu talt om tilskueren i al almindelighed. Men Blue Velvet konstruerer tilsyneladende først og fremmest en »mandlig « tilskuerposition. Igennem identifikationen med Jeffreys projekt tilbydes tilskueren et distanceret, voyeuristisk blik som det primære blik på filmen. Vi ser primært (omend ikke fuldstændigt) det, Jeffrey ser, i sin rolle som detektiv og elsker. Jeg skal nedenfor diskutere filmens voyeurisme-tematik. Men her påpege en væsentlig lakune i denne position, der samtidig bringer forstyrrelse i filmens konstruktion af faste tilskuerpositioner: Jeffreys undersøgende blik er fundamentalt $u$ troverdigt. Og i scenen i Slow Club, hvor Dorothy synger, brydes det detektivisk distancerende, som antydet helt ned.

Ikke blot får tilskuerne til allersidst i filmen at vide, at Jeffrey måske slet ikke har set det, vi har set - eller kun i indre billeder. Men vi er næsten fra starten konstant i tvivl om, hvad det er for øjne, der ser: er det Lovens og Retfærdighedens, eller er det den perverse drifts, der ligger hinsides Loven.

Den overordnede struktur, der i filmens univers er i opløsning og som kan sætte dens uhyggelige forløb i gang, er intet mindre end Faderens Lov og Den ødipale Orden. Denne ikke-eksistens understreges på flere niveauer: I filmens forste scene »kastreres « Jeffreys far af sin haveslange. Senere ser vi ham på hospitalet, reduceret til et væsen uden kontrol over tale eller krop. Dorothys mand Don er også fjernet (han er uvist af hvilken grund kidnappet inden filmens start), ligesom han også symbolsk er blevet kastreret - det er hans øre, Jeffrey finder. Sergent Williams, Sandys far, der officielt leder opklaringen af forbrydelsen, synes ikke at have megen kontrol over situationen og lige så vigtigt: Hans kompagnon, Gordon, i den gule (falskhedens!) jakke er en af forbryderne. Så heller ikke han er til at regne med som overordnet, strukturerende instans. (At dette er tilfældet forudgribes allerede lige efter at Jeffrey har fundet oret: Efter at retsmedicineren har sagt, at det ser ud som om øret er klippet af med en saks, klippes der til et nærbillede af en saks, der klipper en gul (!) snor over, hvorpå der står »Do not cross police lines». Forbrydelsen og retshåndhævelsen kobles altså sammen, eller på det symbolske plan: Faderens Lov og kastrationen). Intet er fast. Betydningen glider hele tiden. Og dog.

Filmens betydningsorganisering følger på et plan primœrprocessernes uorganiserede og uhæmmede vej og benytter sig på et plan af drøm- 
mens u-logiske, u-hierarkiske sprog - bl.a. i sin vedvarende brug af overblendinger. Så det er da nærmest besværgende, at filmen, i overensstemmelse med genrekonventioner, to gange med nærbillede på gadenavne forsøger at forankre sin handling $\mathrm{i}$ et overskueligt og veldefineret rum. På den anden side er filmen ikke et filmsprogligt eksperiment, men en film der skriver sig ind i suspense- (og tildels) gysergenren, og hvis fortælling på overfladen følger løsningen af gåden om det afhuggede ore.

Tilsvarende den primærprocessuelle organisering vil jeg hævde, at filmens symbolske univers er den præødipale fases, og at det er i sin gennemspilning af præødipale strukturer og fantasier, filmen henter sin spænding - og omkring hvilke den strukturerer sin uhygge og suspense:

Frank er rædselsvækkende og frygtindgydende i sin sadistiske ukontrollerethed, men uhyggens sted er Dorothys lejlighed. Til begivenhederne i lejligheden knyttes nogle af suspensegenrens klassiske symboler, f.eks. trappen og det morke rum bag låsede dore og fortællekonventioner som forudgribelsen: dvs. antydninger, der lader tilskuerne vide noget, som filmens personer ikke ved. ${ }^{7}$

Den amerikanske filmforsker Tania Modleski gør i sin bog om (nogle af) Hitchcocks film, The Woman who Knew too Much, opmærksom på forekomsten af trapper i mange Hitchcockfilm, og at de fører op til et rum ovenpå, der knyttes til seksualitet og en kvinde, der er blevet udsat for farer og overgreb. ${ }^{8}$ Det er præcist det, der er på færde i Blue Velvet - og de påfaldende billeder af trappe(opgange) er en af mange intertekstuelle referencer til Hitchcocks produktion. Dorothy bor netop højt oppe - på 7. sal, og man må tage trappen for at komme derop. Lige som trappe-tegnets symbolske værdi allerede antydes i en af de første scener, hvor Jeffreys mor på fjernsynet ser et nærbillede af (mande)fødder der går op ad en trappe (billedet har nærmest emblematisk funktion - selv uden TV'ets lydside ville ingen biograftilskuer være i tvivl om genren ${ }^{9}$ ), får vi med et demonstrativt nærbillede at vide, at elevatoren i Dorothys ejendom er i uorden. Med en subtil henvisning er der dermed indirekte fokuseret på lejligheden som »forbrydelsens sted «: Den bliver overdetermineret, allerede inden Jeffrey og vi forste gang kommer op i den - i hvert fald hvis man genkalder sig det bestialske og sadistisk udpenslede elevatormord i Hitchcockeleven, Brian de Palmas Dressed to Kill (da. Kladt på til mord). Den kvindelige hovedperson Kate bliver straffet for sin seksuelle aktivitet og myrdes af den kvindelige del af hendes - viser det sig - skizofrene psykiater som en symbolsk selvkastration. ${ }^{10}$

Freud prøver i sit essay »Das Unheimliche« (eng. »The Uncan- 
ny«) fra 1919 at bestemme den dybereliggende grund til fornemmelser af uhygge. Han gør opmærksom på den etymologiske glidning mellem ordene »heimlich« og »unheimlich« i det tyske sprog, og på baggrund af forskellige eksempler på, hvad der kan opleves som uhyggeligt: den vedvarende genkomst af det samme, f.eks., eller usikkerheden på om noget dødt er levende, siger han, at det ikke er det nye eller det ukendte, der skaber uhygge. Det er tværtimod det en gang velkendte, der nu er blevet fremmed for bevidstheden gennem fortrængningen. ${ }^{11}$

I en konklusion tager Freud et eksempel op fra psykoanalytisk praksis, der, siger han, »furnishes a beautiful confirmation of our theory of the uncanny «: »Det sker ofte, at neurotiske mænd erklærer, at de føler, der er noget uhyggeligt ved de kvindelige kønsorganer. Dette "unheimliche" sted er imidlertid indgangen til alle menneskers tidligere »heim«, til det sted hvor vi alle hver især tidligere levede - i begyndelsen. Der er en vits, der siger, at kærlighed er hjemve. Og năr en mand drømmer om et sted eller et land og siger til sig selv, i drømme, at: jeg kender det her sted, her har jeg været før, kan vi fortolke det sted som moders køn eller hendes krop. Også i dette tilfælde er »das Unheimliche« det, der en gang var »heimisch«, velkendt; præfikset »un« er fortrængningens mærke. « ${ }^{12}$

Hvad det er på færde i og omkring Dorothys lejlighed er da, at den repræsenterer moders sted. Lejligheden er fremstillet som en (livmoder-)hule: den har rødlilla vægge, for et af vinduerne i køkkenet er der skodder, så at man ikke kan kigge ud, og et rødt fløjlsgardin blafrer i vinden foran et andet vindue, ligeledes som en symbolisering af det kvindelige. Og Dorothy er en mor, der imidlertid er blevet frarøvet sit barn.

Dette sted er for Jeffrey, men også for filmen, på én gang fascinerende og frygtindgydende. Han må vende tilbage til det igen og igen ( $o g$ altid lige efter at han har været sammen med Sandy), men han er også samtidig ved at gå ud af sit gode skind af angst, når han skal derhen; der er således Sandy, der på hans forvirrede spørgsmål om, hvordan han skal finde frem til Dorothys lejlighed i det store hus, må gøre ham opmærksom på, at han kan læse på navneskiltene.

Pointen i at bemærke, at Jeffrey altid opsøger Dorothy, efter at han har været sammen med Sandy, er at dette mønster tematiserer Jeffreys ambivalens: han er umiddelbart splittet mellem sin kærlighed til Sandy og sit begær efter Dorothy, men på et andet niveau splittet mellem et velkendt ødipalt og et skræmmende præødipalt projekt det første er at placere sig i Sandys faders sted i forhold til Sandy og (eller for) derigennem at slippe relationen til »moderen« Dorot- 
hy. ${ }^{13}$ Som jeg skal komme nærmere ind på, er den relation, der af filmen er investeret mest lidenskab i, relationen til Dorothy. Forholdet mellem Jeffrey og Sandy bliver i højere grad beskrevet som et søster/bror forhold end et kærlighedsforhold - understreget af melodidelen af filmens kærlighedstema, der er smægtende og glidende, nærmest sakralt, båret oppe af orglet.

I symbolsk forstand er det, Jeffrey frygter, at nærme sig moderen og den præødipale fase. I den præødipale fase hersker hun og det kvindelige. $\mathrm{Og}$ der er kvindeligheden, moderen og partialdrifterne, der skal fortrænges i drengens psykoseksuelle udvikling frem mod en mandlig kønsidentitet. At bevæge sig ned mod disse lag i psyken er en angstfyldt proces, men ikke desto mindre er en sådan tilnærmning såvel Jeffreys som filmens projekt.

På både et kulturelt og et psykologisk plan synes filmen at sige, at det præødipale projekt er muliggjort (men måske også samtidig nødvendiggjort) af den patriarkalske familiestrukturs opløsning. (Det er denne omfattende problematik, der introduceres med indledningens $\gg$ udslettelse« af Jeffreys far.) Jeffrey begiver sig ud for at lære frygten at kende, dvs. fortrængte lag i sig selv. Hvad han finder, og hvad filmen fremstiller, kan da også bredere ses som forsøg på at give billeder til patriarkatets ubevidste. Tania Modleski mener, at »the patriarchal unconscious lies in femininity ". ${ }^{14}$ Kvindefigurerne er da adækvate repræsentationer af elementer i en mandlig subjektivitet. På det patriarkalsk kulturelles ubevidste scene bliver det kvindelige også hermed håndterligt, når det igennem en slags forskydningsproces bliver knyttet til kvindefigurer, hvis afmystificering er den mandlige hovedpersons projekt. På den måde bliver f.eks. masochistiske strukturer i mandligheden på én gang tematiseret og forskudt. Blot er det ikke hele sandheden om Blue Velvet, for her bliver de også direkte knyttet til Jeffrey.

At Jeffreys præødipale projekt såvel på filmens udsigelsesniveau som for dens instruktør David Lynch og bredere kulturelt - hvad filmens publikumssucces antyder - er et både dragende og skræmmende projekt, ses af to forhold: Det må være magnetisk dragende, i og med at så mange af filmens betydningsfulde scener foregår i Dorothys livmoder-hule. Og det skræmmende i projektet udtrykkes alene af den kendsgerning, at Lynch vælger at benytte sig af suspenseog gysergenren. I gyserens form formidles Jeffreys angst, men også filmens (og dens instruktørs) - og den forplanter sig til tilskueren. Genrevalget er i sig selv et symbolsk udtryk for filmens angst for sig selv: angsten for tilnærmningen til moderen/det kvindelige og for den opløsning, som moderen, det kvindelige og primærprocessuelle står 
for. Det lejlighedskompleks, Dorothy bor i, hedder da også Deep River - pegende på det dybe, ubevidste og det flydende, kvindelige. Men derudover er det i Dorothys lejlighed, at døden placeres. Der finder Jeffrey den døde betjent Gordon og Dorothys døde mand med det afskårne øre, og det er der, Jeffrey tilsidst skyder Frank. Så det kvindelige og moderlige kobles ikke blot med angst men også med død i filmens betydningsstruktur. Så farligt er det.

Men Dorothy selv dør ikke i filmens slutning. Det gør derimod de to ekstremt voldelige mænd: Gordon og Frank, der hver på deres måde er i deres partialdrifters destruktive vold, og så Don, der på sæt og vis hele tiden har været død, som offer for Franks sadisme. Frank er helt ned i de sætninger, han udtaler, opsat på destruktion af det kvindelige og ækvivalerer sin pik med en pistol. Han repræsenterer en patriarkalsk magtopfattelse i dens mest primitive og derfor også mest (selv) destruktive form. "I'll fuck everything that moves ", siger han grandiost ekstatisk i slutningen af scenen hos bøssen Ben. Herfra er der med en metaforisk glidning ikke langt til indholdet i politiordren »Freeze!« - et udtryk for at vold og kærlighed for den perverse Frank er et og det samme. Et andet eksempel er, at ligesom han tager et sug af den iltmaske, han hele tiden bærer rundt på, da han skal voldtage Dorothy, gør han det, da han forsøger at dræbe Jeffrey. Truslen om at knalde alt, der rør sig, antyder også et biseksuelt element i Franks person - ligegyldigt køn vil han kneppe det og - udi egen bevisthed overmande det.

\section{En voyeur}

Beskrivelserne af Jeffrey som voyeur er centrale i filmen: Som Peeping Tom i Dorothys lejlighed, som publikum i The Slow Club og som ufrivillig iagttager i Bens perverse hule. Igennem disse scener undersøger filmen elementer i voyeurismen og det voyeuristiske blik.

Da Sandy, efter et af Jeffreys første besøg i Dorothys lejlighed, forundret spørger ham, om han vil gå tilbage til lejligheden, fortæller han hende om den fascination, han føler ved at se noget, der er skjult for alle andre. Jeffreys projekt er umiddelbart detektivens: at afsløre og få viden. Men erhvervelsen af denne viden bliver af filmen gestaltet som en fantasi om en ulovlig indtrengen i det kvindelige rum - hvor Jeffrey første gang er bevæbnet med en kæmpemæssig insektsprøjte! I symbolsk forstand udtrykkes også hermed ambivalensen i det mandlige projekt; det moderlige bliver ubevidst opfattet som noget, der er befængt med farligt utøj. Tania Modleski citerer Sartre for at forbinde søgen efter viden med et »mandligt« syn og et »mandligt« begær 
(hvad enten det nu er knyttet til manden eller ej). Han bruger således metaforen deflorering for at beskrive, hvad der sker, når man(d) ser: »What is seen is possessed: to see is to deflower. ${ }^{15}$ Sammenholdt hermed kan Jeffreys ulovlige indbrud i Dorothys lejlighed på én gang ses som en sadistisk indtrængen i det kvindelige og en regression til den præødipale fases mor-barn enhed.

Det, Jeffrey bliver vidne til i Dorothys skab, bliver da på sæt og vis en real gennemspilning af det, som han selv blot foretager sig i det små: Franks voldelige og sadistiske indtrængen i Dorothy er psykologisk set forbundet med en regressiv bevægelse: »Baby wants to fuck « siger Frank og involverer sig derefter i en (præ)ødipal fantasi med masochistiske undertoner - at gå i seng med sin mor. Men angsten for moderen og angsten for moderens bemestrende magtfuldhed sætter sig igennem i de sadistiske impulser, hvor han i en omvending bliver den magtfulde »daddy«, der sadistisk gennemspiller en incestuøs fantasi. Sadismen fungerer i Frank som et forsøg på at bemestre en angstfyldt længsel efter sammensmeltning(»I close my eyes/ and I drift away./Into the magic night/ .../ In dreams/ you're mine/ all the time/ ...«) hvor jeg'et vågner og opdager, at han er alene.

Tabuet er et grotesk og uhyggeligt skue. Ben er skæv af stoffer. Han har netop givet Jeffrey en knytnæve i maven, og nu står han henfort "syngende«. Hans makeup gør ansigtet til en stivnet maske, og ligesom uhyggen emmer i rummet og bag lukkede døre, der gemmer på Dorothys kidnappede søn, ulmer volden under melodiens og ordlydens smeltende vellyd. "The candy-coloured clown they call The Sandman«, er Ole Lukøje. Men Der Sandman er også den gotiske fortælling af den tyske romantiske digter E.T.A. Hoffman, som Freud analyserer i »Das Unheimliche«. Heri er Der Sandmann, i følge drengen Nathanaels barnepige, en straffende mand, der kom til børnene, når de ikke ville gå i seng. Han kastede sand i øjnene på dem, så øjnene sprang ud af hovedet, og øjnene tog han med sig i en sæk for at give dem til sine egne børn.

Franks handling og Jeffreys handling er to sider af samme sag. ${ }^{16}$ »Du er ligesom mig« siger Frank til Jeffrey, men det er kun delvis sandt. Jeffrey er mere end Frank, og Jeffreys projekt kan siges at være rettet mod et helt andet mål end Franks - i højere grad at integrere partialdrifterne og kvindelige elementer i et mandligt subjekt frem for destruktivt at lade dem køre deres eget $\operatorname{løb}$ og få overtaget. ${ }^{17}$

I sin kredsen om voyeurproblematikken bærer Blue Velvet mindelser om Hitchcocks film Rear Window (da. Skjulte øjne) fra 1954;Blue Velvet refererer da også intertekstuelt til den i den forstand, at den mandlige hovedperson i Rear Window, der sidder med et brækket ben i sin stue 
og spionerer og observerer lejlighederne overfor sig med en kikkert, hedder Jeffries - blot som efternavn. Ligesom Rear Windows Jeffries har sin lyshårede veninde med det ordinære navn Lisa til at hjælpe sig, har Jeffrey Sandy. Men hvor Sandy på en gang sætter Jeffrey i gang og også kan se sig adskilt fra det, Jeffrey gør, der bliver Lisa direkte den ukampdygtige Jeffries redskab i opklaringen af det mysterium - det kvindemord - han mener at have set på den anden side af gården. Hans projekt bliver også hendes, omend hendes motiv er, at hun vil vinde hans opmærksomhed og kærlighed. Hun tildeles som konsekvens af sin aktive rolle et Blik $\mathrm{i}$ filmen ved siden af Jeffries. Lisas kvindespecifikke viden og snusfornuft bliver vigtig for tolkningen af det, de ser og dermed for løsningen af mordgåden, men ved at tildele sig rollen som Jeffries hjælper, udsætter hun også sig selv for at dø for hustrumorderen Thorwalds hænder.

Modleski konkluderer på sin analyse af filmen, at "på et plan kan Rear Window anskues som en parabel om de farer, det fører med sig, når kvinder bliver involveret i mænds eventyr og mænds fortolkninger (af verden) «. ${ }^{18}$ Men i min fortolkning, hvor kvindefigurerne $i$ Blue Velvet ses som projektioner, som billeder på noget i den mandlige hovedperson, kan det, at Sandy ikke vil have noget direkte at gøre med Jeffreys handlinger og dermed ikke noget at gøre med Dorothy, ses som et udtryk for det kvindeliges problematiske status i det mandlige subjekt - og at det kvindelige i symbolsk forstand må integreres som en blanding af Dorothy og Sandy. For at der er en sammenhæng mellem Sandy og Dorothy antydes af filmen både gennem overblændingerne direkte fra den ene kvinde til den anden og af, at de begge har sådanne fløjlsblå øjne, som Dorothy synger om. (Godt nok er Dorothys kun en maske, nemlig stærkt blå øjenlåg - men netop som maske giver de hende lejlighed til på en gang at udstille sig ekshibitionistisk og at se selv - da hun står på scenen i Slow Club. ${ }^{19}$

Men filmen peger også på, at det ikke nytter noget ikke at ville se at forblive i datter- og skolepigepositionen - hvilket er Sandys rolle hele vejen igennem filmen - og dermed ikke at få indflydelse på fortolkningen af verden. Og den antyder, at der muligvis kan eksistere andre måder at hente viden på end gennem det penetrerende blik, som jo filmen også, paradoksalt nok, benytter sig af og synes at være fanget $i$; $i$ hvert fald har en blind medhjælper i Jeffreys fars butik evnen til at skaffe sig viden ad andre kanaler end gennem synssansen. Han kan altid "se«, hvor mange fingre Jeffrey løfter i vejret foran ham. Sandy selv henvises af filmen til at lytte og få viden. Hun har værelse lige over sin faders kontor i det Torneroseslot, familien bor $\mathrm{i}$. Og selv om det store rødstenshus med tårne som et uigennemtrænge- 
ligt slot antyder, at sergent Williams både er Lovens og Dydens vogter, er Sandy sin far overlegen, i den forstand, at hun ved mere, end han tror, hun ved. Men denne overlegenhed stiller hun alene $i$ Jeffreys tjeneste, lige som den at filmen - mere end til at sige noget om Sandy - bruges til at understøtte beskrivelsen af de vaklende autoritetsstrukturer. ${ }^{20}$

Men Jeffrey ser på Dorothy, og i scenen med Franks indtrængen i Dorothy gennemspiller filmen ødipale og præødipale fantasier. Dorothy involverer sig $\mathrm{i}$ en incestuøs akt med Frank og senere på en måde også med Jeffrey: Hun kalder ham fejlagtigt ved sin mand Dons navn, og derfra er der ikke langt til Donny, som Dorothys søn hedder. Jeffrey bliver endvidere barnet $\mathrm{i}$ urscenen, der observerer forældrenes samleje og også i symbolsk forstand ser moderens »mangel«.

Hvad er det da Jeffrey kigger på? Scenen er filmet i krydsklip mellem Frank og Dorothy og så Jeffrey, der kigger fra skabet. Franks og Dorothys sadomasochistiske akt er filmet i totaler, på distance, mens Dorothys nydelsesfulde ansigt to gange optages i nærbillede. Da hun senere ligger i Jeffreys arme, ser man hendes røde sensuelle mund i et ultranærbillede udtale ordene: »Feel me! Hit me!«. Og senere optræder det samme billede i Jeffreys mareridt - da siger hun blot: »Hit me! Hit me! «. Med deres ophævelse af den rumlige distance peger disse nærbilleder på, at Jeffrey identificerer sig med Dorothy: med hendes smertefulde nydelse og med hendes passive position, til trods for hans - eller samtidig med hans - sadistiske indtrængen i hendes lejlighed. Den masochistiske position knyttes altså også til Jeffreys voyeuristiske position.

De ultranære billeder af den røde mund antyder også, at den distan$c e$, som betinger voyeurismen, er ophævet. De peger på den præødipale fases fragmenterede kropsoplevelse. Og de lægger op til at tale om den slags overidentifikation med Dorothy eller »billedet«, som filmteoretikeren Mary Ann Doane mener karakteriserer den kvindelige tilskuer (jvf. note 5 - her forudsætter jeg, at Jeffrey kan anskues analogt med en biograftilskuer). En sådan fortolkning vil da i forhold til Jeffrey også pege hen på den præødipale fases biseksualitet - og indirekte også på endnu en lighed mellem Frank og Jeffrey: Franks tæuning i slutningen af den »udflugts «-sekvens, der også har ført dem til Bens hule, har homoseksuelle undertoner. Frank har smurt sit eget næseblod på sig som læbestift, så han får en vis lighed med Dorothy, og slagene mod Jeffrey foregår til akkompagnement af hans yndlingsmelodi, Roy Orbisons karlighedssang.

Denne beskrivelse af masochistiske strukturer i Jeffrey svarer til, at den amerikanske filmforsker Kaja Silverman i artiklen »Masochism 
and Subjectivity « (1980) mener, at den passive position og lysten ved smerten er et element $\mathrm{i}$ både den mandlige og den kvindlige subjektstruktur. (Dette kommer hun frem til ved en læsning af Freuds beskrivelse af sit barnebarns fort/da leg, der tager udgangspunkt i en konstatering af, at Freud ikke får forklaret, hoorfor barnet faktisk viser så megen interesse og tilfredsstillelse, når det kaster legetøjet fra sig.) I sammenhæng hermed diskuterer hun Laura Mulveys grundlæggende artikel »Visual Pleasure and Narrative Cinema " (1975), der handler om, hvordan det mandlige ubevidste former og formes af det klassiske Hollywoods fortællende film.

Med udgangspunkt i såvel lacaniansk som freudiansk psykoanalyse diskuterer Mulvey generelt den syns-lyst (visual pleasure), som film-settingen i biografen tilbyder (»the conventional cinematic situation“). Og derefter diskuterer hun, hvordan Hollywoodfilmens fortællekonventioner benytter sig af og former den perceptuelle kønsarbejdsdeling i en patriarkalsk kultur, hvor manden ser, aktivt, og hvor kvinden passivt bliver set på. Hendes grundhypotese er da, at synslysten i den klassiske narrative film har kastrationskomplekset som drivende kraft. Den lystgevinst den mandlige tilskuer tilbydes ligger i et tilbud om identifikation med et bemestrende blik og projekt, hvori kvinden på en gang er seksuelt objekt og samtidig altid repræsenterer det gådefulde andet $o g$ påminder om mangelen. Denne mangels fundamentale trussel for det mandlige har »Hollywood « to strategier overfor: at tildele det kvindelige skyld narrativt og/eller at fetichere det astetisk (f.eks. ved umærkelige brud på diegesen).

Mulvey har - i politisk overensstemmelse med sine teorier - ikke meget tilovers for den klassiske Hollywoodfilm - og derfor fortrænger hun den kvindelige tilskuers eventuelle fascination i forhold til den. I et »Critical Afterthought« (1981), hvori hun i en narrativ analyse bl.a. diskuterer den kvindelige hovedperson i King Vidors Duel in the Sun fra 1946, teoretiserer hun dog også den kvindelige tilskuer. Hun mener, at dennes fascination enten må have form af, hvad hun kalder en "masochistisk identifikation " med den passive heltinde eller have »maskuliniseret« eller »transvestitisk « form ved identifikation med den aktive helt.

Laura Mulveys fascinationsteori er siden 1975 blevet diskuteret, kritiseret og nuanceret. For det første er de kvindelige teoretikere i højere grad begyndt at fokusere på dels TV og dels de såkaldte »women's genres« (f.eks. det klassiske melodrama fra 40'erne i dets forskellige udformninger) og de former for lystinvesteringer de lægger op til. For det andet er Mulveys enstrengede opfattelse af den mandlige subjektivitet, som en modsætningsfri enhed konstitueret igennem 
ødipuskomplekset, problematiseret og nuanceret. ${ }^{21}$

Kaja Silvermans artikel er et bidrag til en sådan nuancering. ${ }^{22}$ Hun mener for det forste, at det - både for den mandlige og kvindlige tilskuer - under alle omstændigheder vil være ofret eller den figur, der indtager den passive position, der har opmærksomheden, fordi tilskueren igennem identifikationen med dennes underkastelse lystfyldt vil genopleve elementer af sin egen historie. Hermed stiller hun altså spørgsmål ved den klassiske freudske aktiv-sadistisk-mandlig/kvindlig-masochistisk-passiv opposition. Dog påpeger hun, at på film knyttes den passivt masochistiske position oftest til en kvindelig figur og den aktive/sadistiske til en mandlig figur, hvorfor den mandlige tilskuer må opleve masochismen igennem en kvindelig stedfortræder.

For det andet diskuterer hun opfattelsen af, at for drenge og mænd skulle oplevelsen af moderen som mangelfuld idelig føre til forsøg på at overkomme kastrationsangsten gennem fetichering af det kvindelige. Silverman mener, at det der skaber angst og krise ikke så meget er synet af og viden om »manglen«, men identifikation med den og med moderen. Og at drengens vej ind i kulturen går via adskillelsen fra moderen og benægtelsen af identifikationen. Hun påstår så bl.a. i forhold til en analyse af Liliana Cavanis Il Portiere di notte (da. Natportieren) fra 1973, at fetichismen er en omvending, der i det skjulte skal fastholde identifikationen igennem formlen, "Jeg er ikke som min mor, men hun er som mig «. ${ }^{23}$

Silvermans artikel giver perspektiver til forståelsen af Jeffrey og til de refleksioner over det mandlige, som Blue Velvet indeholder. Og med scenen hos Dorothy inviteres (også) den mandlige tilskuer til at tage en masochistisk position på sig-om ikke på andre måder så igennem en forskydning - ved identifikation med Dorothy. Andre acceptable positioner eksisterer ikke i denne første del af scenen. Men her, som andre steder i filmen, er blikket (som jeg var inde på tidligere, i betoningen af Jeffreys utroværdige blik) svært at fiksere. Det er, som om Dorothy har på fornemmelsen, at nogen kigger på hende (hvilket - ret beset - får Jeffreys - og tilskuerens - voyeurposition til at vakle): da hun ligger på gulvet foran skabet - inder hun opdager Jeffery - går hun pludselig hurtigt ud af venstre side af billedfeltet, som om hun anede et blik på sig og ville skjule sig for det.

Efter at Jeffrey er kommet ud af skabet, indtager han Dorothys position, med hende som den truende og seksuelt aktive, som den der både vil se og er $\mathrm{i}$ en position til at nægte ham det blik, han før uretmæssig har tiltaget sig: Med løftet brødkniv beder hun ham om at smide tøjet.

Lige som vi som tilskuere ikke så det, Frank beder om at se, da 
Dorothy sidder foran ham med spredte ben, ser vi ikke, hvad Dorothy ser, da Jeffrey har ladet bukserne falde. Og lige som vi så Dorohtys nydende ansigt i den foregående scene, ser vi Jeffreys nu. Igen er det den passivt nydende position, vi som tilskuere - den kvindelige og den mandlige - tilbydes identifikation med. (I forhold til den kvindelige tilskuer er det interessant, at hun făr mulighed for at identificere sig med Jeffreys passivitet, men hun får også mulighed for at identificere sig med Dorothys vrede - på baggrund af den forste del af sekvensen. Når alt kommer til alt er man som tilskuer ikke overbevist om den ordens - eller retfærdighedstrang, der skulle tilføre Jeffreys indtrængen $\mathrm{i}$ hendes lejlighed en slags moralsk berettigelse, endsige til hverken at snuse rundt i den mørke lejlighed eller tillade sig noget så privat - forekommer det - som at bruge Dorothys wc.

Men ligesom der er aktive elementer i Dorothys masochisme og hun formår at placere Jeffrey i en seksuelt sadistisk position, er der sadistiske elementer i Jeffrey, der knytter ham til Frank, også inden Dorothy făr ham provokeret til at slå sig. Efter at være kommet hjem fra Dorothy har han en mareridtsfantasi, hvori han også identificerer sig med Frank: I fantasien ser man, som Jeffrey netop har set det, Frank slå Dorothy, men samtidig toner det ultranærbillede af Dorothy frem, vi - tilskuerne - og Jeffrey så, mens hun lå i Jeffreys arme, efter at Frank er gået. I Jeffreys mareridt siger hun nu »Hit me! Hit me! «, hvor hun i virkeligheden sagde »Touch me! Hit me!«. Dermed afslører Jeffreys fantasi også en sammenhæng $i$ ham mellem at røre og at slå.

\section{Dorothy - Isabella Rossellini-fotomodel}

I forhold til specifikt den kvindelige tilskuers mulige positioner overfor filmen, er scenerne med Dorothy interessante. Og de bliver ikke mindre interessante af, at den vel for de fleste kvinder kendte Lancomemodel, Ingrid Bergmans datter, Isabella Rossellini, lægger ansigt og ikke mindst krop - til Dorothy Vallens person. (Også her er en intertekstuel reference: til den mystiske, døde Carlotta Valdez i Hitchcocks film Vertigo fra 1958, der ligeledes handler om en mand, der begærer en kvinde og til en vis grad identificerer sig med hendes kvindelighed. Carlotta er den mørke slægtning, den kvindelige hovedperson Madeleine foregiver at være helt opslugt af: Carlottas velhavende mand tog deres fælles barn med (»kidnappede« det), da han forlod hende; siden blev hun sindssyg og gik rundt og spurgte alle og enhver, som de havde set hendes barn.)

Isabella Rossellini havde før hun indspillede Blue Velvet spillet hu- 
stru til en til USSR afhoppet amerikansk danser i filmen White Nights (da. Hvide Nætter), men først og fremmest er hun kendt som ansigtet i kosmetikfirmaet Lancomes reklamer. Denne viden er (vel først og fremmest) et kvindeligt publikums viden, når det ser hende synge $\mathbf{i}$ The Slow Club og senere ser hende tage sit tøj af i sin lejlighed. Ved begge lejligheder er hun set gennem Jeffreys øjne. Den første scene, Blue Velvet scenen, hvor Dorothy synger på en scene for et publikum, er en klassisk type kvinderepræsentation i »Hollywoodfilmen«, analyseret af bl.a. Laura Mulvey og E. Ann Kaplan som en repræsentation af den ultimative fetichering af det kvindelige, hvor det smukke objekt er til fals for det mandlige blik - såvel i fiktionen som i biografsalen - og momentvis træder i direkte kontakt med tilskueren (f.eks. i close ups). ${ }^{25}$

Men der meget mere på færde i mange af disse filmscener, efter min mening, og mulighed for mange former for lystinvestering for den kvindelige tilskuer. ${ }^{26}$

Det er der også her, hvor den kvindelige tilskuer ikke nødvendigvis behøver at identificere sig med Jeffreys form for begær.

Sekvensen fra Slow Club starter med en overtoning fra Sandys (fars) hus til klubben, hvis facade kameraet panorerer hen over. Og den slutter med en overtoning fra Dorothys ansigt i profil til Sandys ansigt i modsatrettet profil i Jeffreys bil (hvilket, som tidligere anført, antyder, at der er mere mellem Sandy og Dorothy, end deres mangel på berøringsflade umiddelbart lader ane). Efter at Jeffrey og Sandy har sat sig ved et bord, starter de en besynderlig konversation, hvis indhold dybest set er at fastholde den på det tidspunkt eksitsterende "ødipale« magtkonstellation: Sandy siger, at hendes far drikker "Bud«, efter at Jeffrey har udtalt sin kærlighed til Heineken, og Jeffrey slutter med at kapitulere over for »Bud«: »King of Beers.« Efter denne konversation kommer Dorothy på scenen, og Jeffrey sluger hende med øjnene, $i$ en sådan grad, at tilskueren snydes for noget af hendes nummer: via en overblænding fra Jeffreys ansigt i nært til et totalbillede af Dorothy, springer filmen tidsmæssigt frem til slutningen af sangen. Overblændingen og tidsoverspringet antyder en slags inkorporering af Dorothy og peger mere på en idenfikation med hende (hvilket jo også, som jeg har været inde på, sker i den efterfølgende scene i Dorothys lejlighed). Og vi får et fingerpeg om, at det ikke (altid) er detektivens undersøgende blik, Jeffrey har på.

Spørgsmålet er, om ikke den kvindelige tilskuer tilbydes et detektivisk undersøgende blik. Et blik der er begærligt efter at se på og undersøge, hvad der er i og ikke mindst under det velkendte og utroligt smukke ansigt, hvis alder ugebladenes sladderspalter, siden 
Isabella Rossellini blev givet et navn med White Nights, vedvarende har bragt afsløringer om. Det blik, den kvindelige tilskuer tilbydes, er altså et blik, der er helt anderledes nysgerrigt og nydende end Sandys, der primært er rettet usikkert mod Jeffrey og hans fascination. Måske kan man sige, at den kvindelige tilskuer faktisk - i modsætning til hvad en stor del af den feministiske filmteori lægger op til tilbydes en slags »kvindeligt« voyeuristisk blik, der er vide-begærligt rettet mod en anden kvinde, og en »kvindelig " narcissistisk identifikation med en fuldendt anden - mens det er Jeffrey der overidentificerer sig og derfor ikke kan se.

Som (kvindelig) tilskuer bliver vi snydt for at se det, Jeffrey ikke ser, men at synsvinklen ikke blot er hans, ses af, at vi som tilskuere ser Dorothy synge sangen færdig (for os), efter at Jeffrey og Sandy er gået.

I første del af scenen i Dorothys lejlighed får Dorothy (og Isabella Rossellini) en krop: en bred, blød moderkrop. Både Jeffrey og tilskuerne får lejlighed til at tage den i øjesyn, mens Dorothy står op ad væggen og snakker med Frank og/eller Don i telefonen. Kroppens former understreger, hvad det er for et rum, vi er i. Og da Dorothy med en pludselig bevægelse river - hvad der viser sig at være - en paryk af og afslører det korte, glatte Isabella Rossellini/Lancome hår, både destruerer hun det voyeuristisk fikserende og fortolkende blik og peger ud af fiktionen - på, at Dorothy er et billede, der henviser til et andet billede - det der er nedenunder parykken og udenfor fiktionen. Det er den eneste gang, Dorothy gør opmærksom på, at det sorte, krøllede hår er en paryk. Oplysningen spiller ingen rolle i plot'et; den peger ikke indad i fortællingen, men udad mod tilskueren og det blik, der ser, fascineres og prøver at forstå.

Måske - vil jeg hypotetisk fremføre - kan der være en blanding af sorg og en vis sadistisk fryd tilstede hos den kvindelige tilskuer over at få afsløret, at der er - eller i hvert fald fremstilles billeder - af en ganske almindelig krop under det smukke ansigt. Men man kan også sige, at filmen ved at forudsætte kendskabet til det smukke ansigt, som en del af den kulturelle forhåndsviden, tilskuerne bringer med sig til biografrummet, faktisk giver plads til en kvindelig og en moderlig krop.

\section{Hvorfor er Blue Velvet ikke ubarlig at se?}

Man kan spørge sig selv, hvorfor Blue Velvet, der med sin form og sin klippeteknik minder om drømmen og med sit persongalleri hele tiden antyder paralleller og ligheder mellem sine personer og dermed fly- 
dende grænser mellem personerne - som endelig griber fat i tabuerede og fortrængte elementer i subjektet - man kunne spørge, hvorfor Blue Velvet ikke er så angstvækkende og frygtindgydende en film, så at den ville være ubærlig at se på.

En forklaring herpå er, at samtidig med at Blue Velvet handler om opløsning af grænser og befinder sig i et præødipalt rum - så er den en i høj grad kontrolleret film. Så på én gang tilnærmer filmen sig præødipale strukturer og relationer $o g$ benytter sig af en overordnet fortællende instans, der styrende trækker i sit spils tråde og dermed også både holder publikum i skak og bemestrer sin egen fortælling og dens »unheimliche.«

På den ene side kommer filmens ambivalens i forhold til sit projekt frem her, på den anden side er det styrende, distancerede over-blik også det, der skaber en film.

Den overordnede fortæller viser sig f.eks. i den tydelige, selv-tematiserende kamerabevægelse ned i græsset til billerne i starten af filmen og i den ironisk parodierende indledning med brandbilen og de alt for stærke farver: en alt for blå himmel, alt for røde roser og et stakit, der er alt for hvidt. Men forst og fremmest-viser fortælleren sig i brugen af lyd og især af musikken, som er påfaldende og foruroligende på den måde, at tilskueren gang på gang snydes: vi ved aldrig, hvorfra lyden kommer, om der med andre ord er tale om reailyd eller underlægningsmusik. (Dette tematiseres åbenlyst $i$ scenen hos Ben, hvor vi indtil et vist punkt - via Bens nøjagtige mimen og indlevede poseren - bringes til at tro, at sangen kommer fra Bens mund og ikke fra Franks kassettebånd.) Filmen gør hermed åbenlyst opmærksom på sit sprogs manipulatoriske muligheder. Den skaber selv en ironisk distance til det, den fortæller om (det gælder både dens kærlighedshistorie og dens voldshistorie), og den giver tilskueren mulighed for momentvis at kunne distancere sig fra den på én gang grufulde og fascinerende historie.

I filmens allersidste indstilling, hvor vi endelig ser Dorothy Vallens som mor, kommer Blue Velvet-sangen på lydsiden (sammenholdt) med at smilet stivner på Dorothys ansigt) til at negere billedet af mor/barnforeningen. Filmen devaluerer sin egen billedside og peger igen på en anden viden end den, synet kan give. The Blue Lady er ikke forsvundet; kameraet kører op mod den blå, blå himmel, hvorfra det også startede. Filmen antyder med sin cirkulære bevagelse, at det hele kan starte forfra igen. Men det er påfaldende, at dette billede er det eneste $\mathrm{i}$ en film, der i den grad tematiserer ødipale strukturer, hvor mor-barn enheden visualiseres. Og da altså med en ironisk distancerende lydside. Der er noget, der tyder på, at det umuligt for 
Lynch at give billeder til det, filmen handler om - og at dette visuelle fravær er endnu et eksempel på filmens - og instruktørens - ambivalens. Han både vil og vil ikke.

Men hvordan ender denne film? Hvor placerer den Jeffrey, det kvindelige og det ubevidste? Og vel mest interessant: Hvor placerer den Dorothy, den mørke side af Jeffrey, den ikke-integrerede side?

Også her giver filmen et flertydigt svar. For dels er der en side af Jeffrey - og af filmen - der er opsat på at ødelægge Dorothy - men det bliver den sygelige del, »Frank«, der gør det ved sadistisk at molestere den moderlige krop. Og Jeffrey må - omend nødtvungent - vedkende sig Dorothy og hjælpe hende til live igen. Men den destruktive mandlighed bliver »slået ihjel« - eller: den bliver stirret ind i øjnene, skudt, og dermed kan den muligvis tildeles en mindre destruktiv rolle i det mandlige.

Filmen slutter med en ironisk fortællerinstans' utroværdige fremstilling af en (familie)idyl, hvor der er orden i (køns) rollerne. Den udgør den ene pol i et virkelighedsbillede, der minder lidt om Sandys kærlighedsutopi, hvor Franks sammenkobling af kærlighed og vold udgør den anden. (I Sandys kærlighedsutopi er rødkælke i massevis symbol på, at en lys verden og kærligheden er kommet.) Til denne »familieidyl« ankommer nu én rødkælk. Den sætter sig i vindueskarmen i køkkenet, hvor kvinderne befinder sig - men den har en bille i munden. Så Dorothy eksisterer også i familieidyllen og stadig i Jeffreys bevidsthed - hun er billen. Såvel med distancen til familiebeskrivelsen (f.eks. i de overbelyste billeder og de urealistiske farver) og med Blue Velvet-sangen antydes således, at Jeffreys rejse ned i det ubevidste ikke er afsluttet.

\section{Noter}

1. Den feministiske filmteori, som jo retteligt ikke er én men mange, er (på baggrund af bl.a. lacaniansk og freudiansk psykoanalyse) interesseret $i$, hoordan filmteksten henvender sig til et »du«, hvordan den altså, ved hjælp af en kompliceret sammenhæng mellem point of view strukturer, idenfikationsmønstre og blikudvekslinger i fiktionen, konstruerer en plads for modtageren - tilskueren - og dermed (med)konstruerer et kønnet, et mandligt og et kvindeligt tilskuersubjekt, eller mandlige og kvindelige tilskuerpositioner - som sæde for en lystfyldt udveksling med filmen.

Når der i teorien tales om tilskuere (eng. spectator) tales der om teoretiske konstruktioner, ikke om et realt eksisterende mandligt og kvindeligt publikum (eng. audience). Ejheller forholder teorien sig til, hvorvidt dette publikum nu tager de tilbudte positioner på sig eller ej. Teorien er altså ikke nogen receptionsteori, men en tekstteori, omend man nogen gange synes at fremsæt te hypoteser om forestillede medlemmer af publikum (audience) og ikke om en instans i udsigelsen (spectators). Denne sammenblanding vil jeg dog prove at tydeliggøre, 
hvornår jeg - hvad jeg vil komme til flere gange - fremsætter formodninger om en forestillet kvindelig tilskuer og hvornår jeg, markerende det med gåseerne, taler om »kvindelige« og »mandlige« positioner, uden nødvendigvis at tale om faktiske biologiske køn.

Filmteoretikeren Anette Kuhn har i artiklen Women's Genres (1984) - på baggrund af en diskussion om, hvad det vil sige, at soaps og melodramer er "henvendt til kvinder - provet at udrede forskelle og mulige sammenhænge mellem et maudience« (som hun med en præcisering kalder for »social audience«) og »spectators. « (For navne iøvrigt se litteraturlisten.).

2. Man kan læse om David Lynch og hans film i Cahiers du Cinema 322, 1984, American Film, December 1984, Film Comment, October og December 1986, Monthly Film Bulletin 54, April 1987, Film Quarterly, no. 1, Fall 1987, Cineaste no.3, 1987, American Film, March 1087, Kosmorama $179,1987$.

3. Jeg tænker her på Ridley Scotts Someone to Walch over Me, 1988 (da. Hun så det ske), men især Adrian Lynes Fatal Altraction, 1987 (da. Farligi begær). Senest indeholder Roman Polanskis Frantic, 1988, elementer af samme historie, men Polanski er efter min mening langt mere klar over, hvad hans film handler om, end en instruktør som Lyne.

4. Termen er hentet fra Torben Kragh Grodals artikel "Sherlock Holmes - en professionel voyeur « i Holmgaard og Michaëlis, 1984.

5. Jeffreys blik svarer til tider mest til det blik, som filmteoretikeren Mary Ann Doane (1982) karakteriserer som et kvindeligt blik. "The woman is constructed differently in relation to processes of looking « (s.80), konstaterer hun i overenstemmelse med de øvrige kvindelige teoretikere. Og hun siger - på baggrund af Helène Sixous'og Luce Irigarays teorier, at »that body which is so close continually reminds of the castration which cannot be »fetichized« away. The lack of a distance between seeing and understanding, the mode of judging "in a flash «, is conducive to what might be termed as "overidentification« with the image" (ibid., min understregning).

6. Jfr. afsnittet "Story/Discourse (A Note on two Kinds of Voyeurism) a i Metz, 1985: „The film knows that it is being watched, and yet does not know... The one who knows is the cinema, the institution (and its presence in every film, in the shape of the discourse which is behind the fiction); the one who doesn't want to know is the film, the text (in its final version): the story«(s.95). Afsnittet er første gang trykt pă engelsk i Edinburgh '76 Magazine, no.1: Psycho-analysis/Cinema/Avant-garde.

7. Jeg skal her lade alle de komplicerede tekstuclle og receptionsmæssige problemer omkring at definere, hvad en genre overhovedet er, ligge, men gøre opmærksom på, at dette er Hitchcocks definition af suspense (i modsætning til surprise) i Hitchcock om Hitchcock. Han gør klart, at suspense intet har med skrækeffekter at gøre. Suspense etableres gennem æstetiske og narrative konventioner, men det er også en beskrivelse af en emotionel og kropslig tilstand ved som tilskuer at blive sat $\mathrm{i}$ en position af kun at kunne vente på, at det uafvendelige vil ske, uden selv at kunne gribe ind. Graden af folelsesmæssig involvering afhænger da af, i hvor høj grad man (bringes til) at identificere sig med personerne. (Jfr. videre om suspense og især identifikationsbegrebet i Palle Schantz Lauridsen, 1985).

Suspense opbygges fortællemæssigt oftest gennem krydsklip. I scenen umiddelbart før Frank tager Jeffrey og Dorothy med på den farlige »familieudflugt « opbygges i virkeligheden en blanding af suspense og surprise. Scenen foregår i Dorothys lejlighed, med et enkelt klip til den tomme trappeopgang. Netop da Jeffrey skal til at gå, overraskes han og Dorothy i døråbningen af Frank. Havde »krydsklipningen« her opbygget klassisk suspense, var vi som tilskuere ved selvsyn blevet klar over, at Frank og hans kumpaner var på vej op ad trappen. Vi ser trappen, og vi aner - for hvorfor skulle vi ellers se den, men da Frank faktisk træder frem foran Jeffrey og Dorothy, gyser vi.

8. Modleski 1988, s. 18.

9. Betydningen af TV/billedet understreges af, at Jeffrey i scenens 1. indstilling, i et suggestivt frøperspektivbillede, går ned ad trappen til stuen, hvor moderen og tanten sidder. Da Jeffrey siger, at han går ud, sporger moderen bekymret: »Du går ikke hen til Lincoln, vel? « - og det forbudte sted, Lincoln, er - viser det sig - navnet på den gade, som Dorothy bor i.

10. Jfr. Williams, 1984. Jeg skal senere i analysen vende tilbage til Hitchcock-referencerne. 
Min kollega Søren F. Lund har giort mig opmærksom på de referencer, filmen direkte og indirekte har til 60'ernes Batman 'TV-serie. Jeffreys svar på Sandys spørgsmål om, hvorvidt han er "pervert« eller "detective«: "That's for me to know and you to find out er da også et Batman-citat.

11. Freud, 1919, s.224.

12. ibid., s.245 (min oversattelse).

13. Scenen, hvor Jeffrey forste gang kommer over til sergent Williams for at tale med ham om mysteriet indledes med, at kameraet kører ud fra et fotografi i ramme af Sandy, på faderens bord, til en total af de to mænd. Hermed er den ubevidste rivalisering mellem Jeffrey og Williams antydet, som filmen flere gange senere tematiserer.

14. Modleski, op.cit., s. 4 .

15. ibid., s.63 - Modleski citerer fra den engelske oversættelse af L'etre et le néant (1943).

16. Lydsiden bruges også til at skabe lighed mellem Frank og Jeffrey. Da Jeffrey under et af sine senere møder med Dorothy slår hende, er lydsiden den samme som under et nærbillede af Franks forvredne ansigt i en mareridtsdram, Jeffrey har, efter at han har overværet scenen mellem Frank og Dorothy.

17. Hvordan denne subjektivitet skal se ud, har filmen ikke noget bud på. En anden af de mandlige varianter, bøssen Ben, synes blot at have iklædt sig kvindelige træk som en maske. Han er dybest set lige så sadistisk som Frank - blot doper han sadismen i narkotika.

18. Modleski, op.cit., s.81 - min oversættelse.

19. En lignende tolkning af øjen-make up'ens symbolske funktion for kvinder foretager Hanne Mølier i en diskussion af 60'ernes kvindelighedsudvikling, i Møller (1988/89).

20. Jfr. om Sandy/figuren i Biga, 1987. Tracy Biga tildeler - i sin udmærkede analyse af filmen - Sandy et undersegende (investigative) og et bekraftende (affirmative) blik. Med det undersøgende, uneurotiske blik, kan hun se, fortolke og forstå, mener Biga, og det giver hende en vis frihed $\mathrm{i}$ forhold til Jeffreys projekt. Biga slutter lidt moralsk af med at mene, at dog er Sandy ikke nogen heltinde for feminister: "Sandy looks, but although she is firmly established as the sexual partner - as Dorothy is established as the mother - she is hardly available for feminist appropriation. Investigation and affiliativeness are valuable and valid, but perhaps it is time the gaze shifted." Men - for det første har det nu engang ikke været Lynchs projekt at lave en film om Sandy - eller en anden kvinde for den sags skyld. For det andet må det også være mere spændende, at det er kvinder - og kvindelige instruktører der vender det blik om.

21. I bøger og en lang række artikler i tidsskrifter som Screen, Camera, Obscura, Framework og Wide-Angle. Endvidere i de i denne artikel næunte Doane 1982 og 1987 og Modleski 1988.

22. Silverman, 1980. Gaylyn Studlar (1985) beskæftiger sig ligeledes med den mandlige tilskuers masochistisk farvede lyst i bografen. Hun anfører ogsi̊ interessante synspunkter på suspenseopbygning, som hun mener er noget andet end "accelerating repetition of action" (s.605), nemlig snarere en del af en "masochistic aesthetic (ibid.). Heroverfor kritiserer Tania Modleski i en af sine mere militante bemærkninger begge kvinder far at se fuldstændig bort fra "sadism in the male viewer's response« (1988, s.12). Det kan godt være, det har varet et »blind spot « eller "repressed aspect «, indrømmer hun, men det, der interesserer Modleski, er: "what are the sources and consequences of the "dread of women «, of »ambivalencess towards the mother, of the equation of women with death, all of which are mentioned by Studlar as crucial components of the masochistic aesthetic? « (ibid.,s.11).

23. Silverman, 1980, s.6.

24. Jfr. Modleskis analyse af Vertigo i Modleski, 1988.

25. Jfr. Laura Mulvey, (1975), og Ann Kaplans analyse af Josef von Sternbergs Blonde Venus i Kaplan (1983).

26. Og for danse- og syngescener i mange klassisk fortællende film tror jeg det galder, at de tilbyder et andet (erotiseret?) blik for kvinder end blot identifikation med den mandlige tilskuers - netop fordi sădanne scener har tendens til at lessrive sig fra fortællingen.

Kaplan skriver om Blonde Venus, at denne er wa film clearly constructed for the male spectator, using as its method of domination women in its representational system that of fetishizing the female form« (Kaplan, 1983, s.50). Mulvey bruger scener fra von Sternbergs 
Morocco, ligeledes med Marlene Dietrich i hovedrollen, til at fremfore den samme hypotese - kvinden repræsenterer kun "to-be-looked-at-ness. « Endelig taler hun, ligesom den nu afdøde engelske filmteoretiker Claire Johnston, om at hele stjernesystemet er bygget op omkring en fetichering af det kvindelige.

Mulveys tekst må forstås i sin historiske specifitet, dels om et banebrydende forsøg på at bidrage til en feministisk tekst-teori og dermed at komme uden om blot kvantitativt at talle kvinder og mænd i film. Men også som et stykke feministisk ideologikritik, uden historiske præciseringer og med en total fortrængning af de personlige lystinvesteringer (ambivalente eller ej), hun selv måtte have lagt $\mathrm{i}$ at se Hollywood-film. I sidste del af sit „Critical Afterthought er hun i virkeligheden meget mere spændende end i "Visual Pleasure", synes jeg, idet hun frem for at komme med løsrevne (og alt for forsimplede) betragtninger over feks. Marlene Dietrichs fremtræden i Morocco, forsøger at fremanalysere et narrativt manster som en symbolisering af en kvindelighedsudvikling. Efter min mening må man nødvendigvis, når man snakker om skue-lyst og om de former for lystinvestering, der kny ttes til blikke og blikudvekslinger $\mathrm{i}$ diegesen analysere dem i forhold til - og på baggrund af hele den kontekst, som forløbet, narrativiteten, er - og som man også som tilskuer forstår og fortolker mobjektiverende " eller »feticherende « blikke $i$ forhold til. Og som på et andet teoretisk grundlag er en del af den udsigelse, som konstruerer subjektpositioner.

\section{Litteratur}

Biga, Tracy: »Blue Velvet», Film Quarterly, volume XLI, no. 1, Fall 1987.

-: "Film and the Masquerade: Theorising the Female Spectator«, Screen, vol.23. no.3-4, 1982.

Doane, Mary Ann: The Desire to Desire. The Women's Film of the 1940s, MacMillan Press, 1987.

Freud, Sigmund: "The Uncannya(1919), in The Standard Edition of the Complete Psychological Works of Sigmund Freud.

Grodal, Torben Kragh: »Sherlock Holmes - En professionel voyeur «, in Holmgaard og Bo Tao Michä̈lis: Lystmord, 1984.

Johnston, Claire: "Women's Cinemas as Countercinema«, in Bill Nichols (ed.) Movies and Methods, vol.I, University of California Press, 1976.

Kaplan, E. Ann: Women and Film. Both Sides of the Camera, Methuen 1983.

Kuhn, Anette: »Women's Genres«, Screen, vol.25, no.1, 1984.

Lauridsen, Palle Schantz: „Og Gud skabte mennesket i sit billede - Noter om film og identifikation", in Litteratur og samfund 40, 1985.

Metz, Christian: Psychoanalysis and Cinema. The Imaginary Signifier, Mac.Millan, 1985.

Modleski, Tania: The Women zeho Knew too Much. Hitchcock and Feminist Theory, Methuen 1988.

Mulvey, Laura: "Visual Pleasure and Narrative Cinema «, Screen, vol.16. mo.3, 1975.

Mulvey, Laura: "Afterthoughts on "Visual Pleasure and Narrative Cinema», inspired by "Duel in the Sun «, Framework 15, 1981.

Møller, Hanne: »De søde, de mutte og de rå. Pigekultur og kvindelighed 1958-64, set ud fra rockmusikken. « (Artiklen publiceres i den kommende Arbog for ungdomskulturforskning 3, 1988 89.)

Silverman, Kaja: »Masochism and Subjectivity«, Framework 12, 1980.

Studlar, Gaylyn: "Masochism and the Perverse Pleasures of the Cinema «, in Bill Nichols (ed.): Movies and Methods, vol.II, University of California Press, 1985.

Truffaut, François: Hitchcock om Hitchcock, Rhodos, 1973.

Williams, Linda: "When the Woman Looks«, in Mary Ann Doane, Patricia Mellencamp and Linda Wiliams (eds.): Re-Vision, The American Film Institute, 1984.

Om instruktøren og hans film (småartikler, anmeldelser og interviews): 
Cahiers du Cinéma 322

American Film, December 1984

Film Comment, October 1986

Film Comment, December 1986

Monthly Film Bulletin 54, April 1987

Cinéaste 3, 1987

American Film, March 1987

Kosmorama 179, 1987

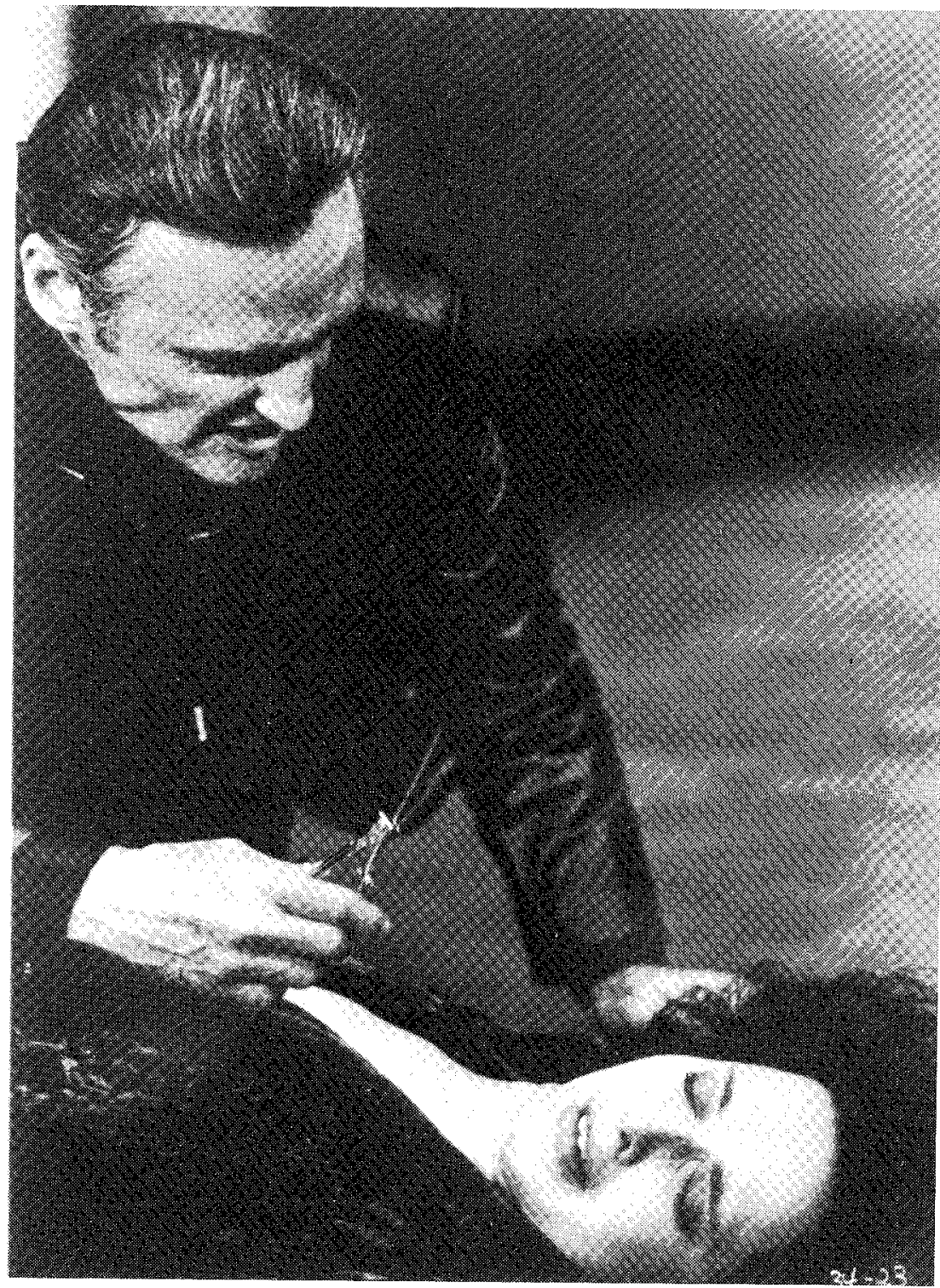

Dennis Hopper og Isabella Rossellini som Frank og Dorothy. 